\title{
Mentoring is an Intellectual Pillar of Ethnobiology
}

\author{
OPENӘACCESS \\ DOI 10.14237/ebl.10.1.2019.1656
}

\begin{abstract}
Copyright (c) 2019 by the author(s) licensee Society of Ethnobiology. This is an open-access article distributed under the terms of the Creative Commons Attribution-NonCommercial 4.0 International Public License (https://creativecommons.org/licenses/by-nc/4.0), which permits non-commercial use, distribution, and reproduction in any medium, provided the original author and source are credited.
\end{abstract}

There is a lot being written right now, and rightfully so, about bad mentorship. Like media companies and the government, academic researchers also abuse the power they hold. Personal relationships can be leveraged, established figures can face little oversight for inappropriate behavior toward junior colleagues, and these hurtful and harmful interactions are written off by administrations as the singular deeds of bad actors rather than a systemic power imbalance that requires systemic change. Victims are frequently gaslighted and forced to continually question their own feelings. There are several reasons why this should trouble ethnobiologists.

The prevalence of mentors who discriminate, abuse, or otherwise discourage researchers of all career stages with whom they collaborate damages the field for years to come. Abuse in academia is pervasive, with 948 resolved and ongoing cases in the Academic Sexual Misconduct Database (Libarkin 2019). Bestselling authors such as Robin Kimmerer reflect on being told that science is "not for them" (Kimmerer 2015), while a recent and wellpublicized survey of anthropology field research experiences noted that an unacceptable $72.4 \%$ of participants directly observed or heard about inappropriate sexual remarks or harassment at their most recent or notable field site (Clancy et al. 2014). Each time that major research institutions systematically marginalize female researchers (Wadman 2018), academic conferences struggle to expel serial abusers (Wade 2019), laboratory leaders dismiss gender imbalances as states of nature (Conradi 2019), and senior faculty use tenure to defend themselves against transgressions that have nothing to do with their intellectual freedom (Anderson 2018), we lose promising and valuable perspectives in favor of an abusive status quo.

Ethnobiology relies on community partnerships and relationships between elders or other knowledge keepers and students. Our Society of Ethnobiology (Society), like all academic organizations, has its own issues with discrimination and abuses of power. But more than other academic disciplines, contemporary ethnobiology is practiced with and strengthened by close, respectful working relationships. Indeed, our Society's most popular recent work (e.g., Bonta et al. 2017; Randrianandrasana and Berenbaum 2015) showcases scientific research designed and led by indigenous and female scholars. There is no ethnobiology without elders or diverse voices. Their absence would doom some of our best scholarship, particularly that based in Ethnobiology 5 (Wolverton 2013), in which research builds socioecological theory while addressing the moral and political need to strengthen coalitions that support local knowledge and sovereignty to live with rapid shifts in ecological, political, and economic opportunities for communities around the world. To do ethnobiology requires field research, respectful exchanges of knowledge, team-based collaboration, and, above all, careful mentoring. Discussions regarding collaboration and ethics are cornerstones of contemporary ethnobiology (Medinaceli 2018; SOLAE Ethics Committee et al. 2018). As such, we offer our thoughts on the lessons ethnobiology brings to mentorship and accountability while outlining some of the specific steps we are taking as an academic and practicing community.

\section{Codes are Important}

Ethnobiology as a discipline is increasingly and rightfully concerned with ethical collaborations between researchers and knowledge-holding communities, as discussed in a recent special issue of Ethnobiology Letters edited by Cynthia Fowler and Scott Herron (2018), to name one of many discussions. Authors in that collection and a recent review of anthropology field experiences (Nelson et al. 2017) note the value of strict codes of conduct and oversight that give students and faculty clear direction for their behavior and practice. Spurred by these external and internal concerns, the Society of 
Ethnobiology recently drafted a code of professional conduct for its members.

The discussion of how our Society might craft an appropriate code of conduct for our members began around the time of the 2018 combined annual conference of the Society of Ethnobiology and the Society for Economic Botany (SEB) in Madison, Wisconsin. In preparation for the joint conference, we circulated the recently adopted SEB Code of Conduct to conference registrants in May 2018 (Society for Economic Botany 2018). The Code of Conduct was discussed at the Society board meeting in Madison, as it was throughout the conference, and continued as a priority for the Society's board in the months that followed. The Society President at the time, Cynthia Fowler, led a subcommittee on the task of constructing the "Society of Ethnobiology Code of Professional Conduct for Meetings and Other SOE Events" during the following months. At the 2019 Annual Conference in Vancouver, Canada, Fowler and Vice President Sarah Walshaw held open forum workshops, which allowed conference attendees to share ideas, concerns, and suggestions for the Society of Ethnobiology Code of Conduct. In the process of preparing and drafting the Code of Conduct, society members also explored ways of creating Safe Spaces and inclusivity at our meetings and events. The Code of Professional Conduct remains a work in progress, as the committee continues to solicit input and advice from members. We hope it will be ready for ratification by the membership at the 2020 Annual Conference in Cedar City, Utah.

As social and ecological researchers, we recognize that our institutions are built through daily practices. That is, our codes and ethical programs must be lived and modeled by senior and junior members. Unlike many of the larger disciplinary conferences our members attend, the panel discussions at the Annual Conference of the Society tend to have large audiences, in part because they are not overscheduled, but also because there is an institutional culture of attending talks and listening to sessions. Thus, emeriti professors can learn about cutting-edge research by students and students can learn professional expectations from senior colleagues. Through this atmosphere, we aim to foster a sense of sharing and respect that encourages audience members to attend entire sessions. The Society conference invites a diversity of voices, ranging from academic to non-academic, industry, and Indigenous, with the understanding that many people fall into several of these categories. Because ethnobiology is inherently interdisciplinary, field research teams share training and expertise, and the resulting academic writing shares credit and authorship. This helps to maintain the understanding that everyone's contributions are valuable in our discipline. We see the results of this practice in our publications, and over the last five years research articles published in regular issues of Ethnobiology Letters have had an average of three authors, including many students.

\section{Demystifying Academic Progress}

Academic achievement is dominated by the quest for ever more publications, grants, and scholarly products that establish our voices in the field. Published peerreviewed research and grant success, or at least the potential to achieve such, is a requirement to attain most academic and research positions, and yet many students and junior scholars have little experience with peer review or the publication process. In many cases, this is because students and junior scholars are still exploring new approaches in their research agendas. Mentors have a responsibility to step in and encourage mentees to pursue their interests along a more focused academic path by emphasizing the importance of clear deliverables, i.e., publications or conference presentations. As qualitative social science warms to the idea of multiple authorship, mentors can take pride in second-authorship that results from these collaborations. Outside of academia, many ethnobiologists communicate with a broad audience that may include specialists across a wide range of disciplinary backgrounds. Collaborative projects build in feedback systems where speakers can hone the art of communicating with different audiences.

Writing pedagogy is becoming an increasingly important part of students' training through the spread of writing labs, revision-based course assignments, and professional development training at universities. Often, junior faculty credit writing groups as essential to their dissertation process, and the National Center for Faculty Diversity and Development recommends writing groups as a way to reinforce accountability and achievable goals at the faculty level as well (National Center for Faculty Diversity and Development 2019). Writing groups not only help researchers organize their data, they create a space to build comradery and provide a framework to support ongoing writing at all stages (Silvia 2019). Through these groups, writers learn how to give and 
receive peer review that is specific, actionable, and constructive. As with the larger craft of writing itself, this process eases some of the initial stress that junior scholars experience in submitting articles to peerreviewed journals, presses, and other venues. To promote the type of writing often done more readily by early-career scholars, Ethnobiology Letters publishes "Short Topical Reviews" that are particularly friendly to well-focused studies such as those often completed by students, and the Society blog "Forage!" has developed a list of best practices and prompts for interested new writers.

Similarly, journal clubs play well to the interdisciplinary strength of ethnobiology as an academic field, because ethnobiological researchers must become comfortable explaining their work to an audience outside that of their disciplinary training. When such a group reads work by ecologists, an audience that may include taxonomists, botanists, and political ecologists learns to bring their particular perspective to the issues at hand. Such groups foster interdisciplinary collaboration by providing the initial space for new cross-disciplinary discussions to emerge.

In such settings, the space itself is critical. Mentors have a special role in these groups by ensuring that group members feel comfortable giving and receiving critiques. This may mean that mentors have to coach group members on respectful dialogue, and it will require mentors to model this behavior themselves. Through deeply personal gestures, mentors may ease some of the vulnerabilities in a writing group by sharing their own process and some of their own setbacks-no senior faculty member has been unscathed by an unkind review. The opposite circumstance, in which mentors fail to make the group a comfortable space, where criticism is vague, or where junior members are punished in their institutions for a low number of publications or grants without being assisted by senior colleagues to join projects or working groups, is sure to discourage innovation and curb the field's intellectual growth. Just showing up to these events is an expenditure of time and resources by mentors and junior members. By creating comfortable spaces in which to grow intellectually, we achieve academic benchmarks without the mystery and stress than can surround career advancement. Hopefully, this creates a richer, more positive experience for everyone involved.

\section{Promoting Positive Field Experiences}

Much ethnobiological research and practice is done within communities, with groups of nonethnobiologists, and at the intersection of natural and social science approaches. Ethnobiological field schools, disciplinarily focused on sharing ecological knowledge, empowering local communities, and expanding academic understandings of humanenvironmental relationships, can be an invaluable way to recruit future ethnobiologists and cement ongoing partnerships. Students benefit from the chance to try new methods and approaches, while partner communities have the opportunity to complete laborintensive projects or assess ongoing programs. By modeling what community partnerships, professional behavior, and responsible research look like, mentors shape both student and community visions of ethnobiology. Many faculty and senior research members of our Society take students into the field with them where they collaborate on research projects. These trips typically include between one and four graduate students who are collecting data either as part of the advisor's larger research program, or for their own research for a thesis or publication as part of the team. The funding sources for smaller research trips with a mentor can come through existing research grant funds, soliciting institutional research or student-mentoring grants, student-solicited research grants, or pre-existing institutional funds.

The National Science Foundation has offered a series of field-school programs and methods workshops to enhance and supplement the training provided in the traditional graduate school setting. By taking junior scholars and students into field experiences in places as diverse as the Bolivian Amazon or rural Namibia, they give hands-on and direct mentoring of the utility of various anthropological field research techniques while also being exposed to the ways that responsible and ethical community relationships are established and maintained. Various universities and institutions also sponsor summer field schools, such as the annual ethnographic field school in Belize led by Douglas Hume.

In Kampsville, Illinois, the Center for American Archaeology has introduced a combined ethnographic and archaeological field school where students ask similar questions about human-environmental relationships in past and present contexts. This field 
school is fully funded for participants and kept small to encourage hands-on learning and introduce students to research as a profession. Here, farmers are invited to the research and students are trained to see them as partners in historical preservation and ongoing ecological stewardship.

Research on student experiences with field schools is unambiguous (Clancy et al. 2014; Nelson et al. 2017): mentors must provide clear rules of conduct, have a chain of accountability, and treat all participants with respect, in order for the field school to run successfully. However, students can have a positive experience even while community partners desire different kinds of interaction, as described in Guthman's (2008) study of well-meaning college students working to improve community gardens and food options in California. As facilitators, mentors have a responsibility to ensure both that students learn and that community leaders are active collaborators in creating a research plan that meets their needs.

\section{Planting Seeds}

Much of this editorial has focused on the important role that mentors play in creating spaces: spaces where ideas can germinate, people with different disciplinary assumptions can talk to one another, and where partner communities trust the people with whom they share their knowledge. Like planting seeds, this work must be active, in which some of the emphasis is removed from students by asking mentors to volunteer space, time, and recruitment to diversify the academy. One such model comes from the Santa Fe Institute, which gives space and freedom for people of many disciplines to work through research plans, and to collaborate and discuss with one another. If a goal of contemporary ethnobiology is to bridge traditional academic boundaries, broaden the community of ethnobiologists, and put that knowledge to use to solve pressing environmental and social crises (Wolverton 2013), then mentors have an outsized responsibility in facilitating this work. In modeling how to conduct research and speak across disciplines, ethnobiology mentors can provide an umbrella under which a range of interdisciplinary scholars work toward conservation and human rights. The Society's recent Distinguished Ethnobiologist honorees, including Nancy Turner, Gary Nabhan, Gene Hunn, Gene Anderson, Steve Emslie, Steve Weber, and Jan Salick, have all worked to create such spaces at the intersection of social and ecological inquiry. Furthermore, their acceptance speeches have credited their own mentors, including both formal academic researchers and elders and other knowledgeholders with whom they have worked.

Although this has been a largely celebratory editorial, the creation of sustainable mentoring infrastructure remains extremely important if we are to make good on the promise of diversity and inclusion in the scholarly umbrella of ethnobiology. Codifying, institutionalizing, and, yes, funding mentoring activities is essential to sustaining these gains in the age of neoliberal university education that values particular metrics of productivity while devaluing other activities as wasted time. It is not enough to simply remember the mentors who helped us. Let us build the systems to pay it forward.

\section{References Cited}

Anderson, N. 2018. Academia's \#MeToo Moment: Women Accuse Professors of Sexual Misconduct. Washington Post, May 10, 2018, sec. Education. Available at: https://www.washingtonpost.com/ local/education/academias-metoo-moment-womenaccuse-professors-of-sexualmisconduct/2018/05/10/474102de-2631-11e8874b-d517e912f125_story.html. Accessed on December 1, 2019.

Bonta, M., R. Gosford, D. Eussen, N. Ferguson, E. Loveless, and M. Witwer. 2017. Intentional FireSpreading by "Firehawk" Raptors in Northern Australia. Journal of Ethnobiology 37:700-718. DOI:10.2993/0278-0771-37.4.700.

Clancy, K. B. H., R. G. Nelson, J. N. Rutherford, and K. Hinde. 2014. Survey of Academic Field Experiences (SAFE): Trainees Report Harassment and Assault. PLOS ONE 9:e102172. DOI:10.1371/ journal.pone.0102172.

Conradi, P. 2019. Alessandro Strumia: The Data Doesn't Lie-Women Don't like Physics. The Sunday Times, March 24, 2019, sec. News Review. Available at: https://www.thetimes.co.uk/article/ alessandro-strumia-the-data-doesnt-lie-women-dontlike-physics-j10bpfd9t. Accessed on December 1, 2019.

Fowler, C. T., and S. Herron. 2018. The Long Program for Ethics in Ethnobiology. Ethnobiology Letters 9:1-3. DOI:10.14237/ebl.9.1.2018.1356.

Guthman, J. 2008. Bringing Good Food to Others: Investigating the Subjects of Alternative Food 
Practice. Cultural Geographies 15:431-47. DOI:10.1177/1474474008094315.

Kimmerer, R. W. 2015. Braiding Sweetgrass: Indigenous Wisdom, Scientific Knowledge and the Teachings of Plants. Milkweed Editions, Minneapolis, MN.

Libarkin, J. 2019. Academic Sexual Misconduct Database. Academic Sexual Misconduct Database [web page]. Available at: https://academic-sexualmisconduct-database.org/. Accessed on December 1, 2019.

Medinaceli, A. 2018. Taking an Early Step in Ethnobiological Research: A Proposal for Obtaining Prior and Informed Consent from Indigenous Peoples. Ethnobiology Letters 9:76-85. DOI:10.14237/ebl.9.1.2018.1054.

National Center for Faculty Diversity and Development. 2019. Faculty Diversity [web page]. Available at: https://www.facultydiversity.org/. Accessed on December 1, 2019.

Nelson, R. G., J. N. Rutherford, K. Hinde, and K. B. H. Clancy. 2017. Signaling Safety: Characterizing Fieldwork Experiences and Their Implications for Career Trajectories. American Anthropologist 119:71022. DOI:10.1111/aman.12929.

Randrianandrasana, M., and M. R. Berenbaum. 2015. Edible Non-Crustacean Arthropods in Rural Communities of Madagascar. Journal of Ethnobiology 35:354-83. DOI:10.2993/etbi-35-02-354-383.1.
Silvia, P. J. 2019. How to Write a Lot: A Practical Guide to Productive Academic Writing. Second Edition. APA LifeTools, Washington, DC.

Society for Economic Botany. 2018. Code of Conduct [web page]. Available at: http://www.econbot.org/ home/governance/code-of-conduct.html. Accessed on December 1, 2019.

SOLAE Ethics Committee, Armando Medinaceli, Eréndira J. Cano, Arturo Argueta, and Olga Lucia Sanabria. 2018. Latin American Society of Ethnobiology's Code of Ethics. Ethnobiology Letters 9:86-89. DOI:10.14237/ebl.9.1.2018.1121.

Wade, L. 2019. \#MeToo Controversy Erupts at Archaeology Meeting. Science, April 15, 2019. DOI:10.1126/science.aax7037.

Wadman, M. 2018. Salk Institute Settles Last of Three Gender Discrimination Lawsuits. Science, November 21, 2018. DOI:10.1126/science.aaw1383.

Wolverton, S. 2013. Ethnobiology 5: Interdisciplinarity in an Era of Rapid Environmental Change. Ethnobiology Letters 4:21-25. DOI:10.14237/ ebl.4.2013.11.

\section{December 4, 2019}

\section{Andrew Flachs}

Department of Anthropology, Purdue University, West Lafayette, USA. aflachs@purdue.edu

\section{Elizabeth A. Olson}

Department of History, Sociology, and Anthropology, Southern Utah University, Cedar City, USA. elizabetholson@suu.edu

John M. Marston

Department of Anthropology, Boston University, Boston, USA.

marston@bu.edu

Andrew Gillreath-Brown

Department of Anthropology, Washington State University, Pullman, USA.

andrew.d.brown@wsu.edu 